\title{
A Survey Of New Product Development: Can Decentralization Alone Deliver?
}

Aya S. Chacar, Florida International University, USA

Krishnamurthy Surysekar, Florida International University, USA

\begin{abstract}
Geographic decentralization of the new product development (NPD) process is seen by many as a necessary means to increase innovation and its cost-effectiveness. Decentralization promotes innovation in many ways, especially by allowing better access to local knowledge pools. This study's results, based on a survey of top executives in large manufacturing firms around the globe, give only mixed support to this view. Decentralization is associated with increases in revenues from new product but the performance of firms with geographically decentralized NPD is inferior otherwise. The key culprits seem to be the decrease in involvement of NPD stakeholders in firms with geographically decentralized NPD and the inability of firms with geographically decentralized NPD to generate a greater level of radical innovations. The study results are broadly consistent with academic research in this area.
\end{abstract}

Keywords: new product development, knowledge transfer, global centralization, global decentralization.

\section{INTRODUCTION}

1 n this research note, we report on the results of an international survey of senior business executives involved in new product development (NPD). The survey was conducted during the period 1999-2000 by one of the world's leading accounting and management consulting firms. Our key result is that geographically decentralized new product development is consistent with greater revenues from new products. However, senior managers involved in decentralized NPD perceive poorer performance than those involved in centralized NPD. Key reasons are analyzed and they are consistent with academic research in this area. This paper fills a void in survey data related to NPD that can be juxtaposed with conceptual research.

In their seminal review paper on knowledge management research, Alavi and Leidner (2001) stress the importance of research on attributes of organizational settings that facilitate knowledge flows. They further note (p. 111) that a key focus of knowledge management should be "knowledge flows, and the process of creation, sharing and distributing knowledge." Hatch and Mowery (1998) survey the semiconductor industry. They note that proximity between development and manufacturing facilities help improve performance when new technologies are introduced. The focus of our paper, new product development lends itself nicely to this stream of research. PennerHahn (1999) notes how the "market adaptation" motive for international dispersion of R\&D has now evolved into "knowledge and expertise tapping" as a motive for the increasing internationalization of R\&D. Gilbert (2004) studies new ventures and finds a significant positive association between industry clustering in a geographic location and the venture's product innovation and growth performance.

The debate over whether centralization or delegation is better at delivering business performance has been going on for decades. At the most general level, delegation ${ }^{1}$ leverages local informational advantages but creates coordination problems, especially when the managerial activities are significantly linked. Centralization, on the other hand, helps with the coordination. However, it could result in delays, information losses, and overall inefficiencies. Severinov (2008) provides several interesting examples from procurement and manufacturing to illustrate the trade-offs associated with delegation and centralization. Baliga and Jaeger (1984) provide a conceptual framework for looking at delegation issues in multinational corporations. They note that interdependencies, "cultural proximity" and environmental uncertainty should all guide the level of delegation and choice of control 
systems. Melumad and Reichelstein (1985) consider an economic model that involves centralization, delegation and communication of information between a subordinate and the supervisory unit. They conclude that, under most usual conditions, a scheme that involves centralized decision making based on communications from the subordinate unit is preferable to a situation of delegation without communication.

Despite a number of general approaches identified above, there is surprisingly very little academic work done in the area of how organizational structure issues, particularly the extent of centralization and delegation, affect the process, and subsequent performance evaluation of new product development activities in manufacturing firms. Thus, the results reported in the paper can serve as a starting point for further empirical investigations into this question.

\section{RESEARCH DESIGN}

The survey is based on personal interviews with and written responses to a detailed questionnaire from 70 executives from 29 large manufacturing firms, where new product development was known to be important. The process was started and substantially completed in 1999-2000. The manufacturing companies were from the US, Europe, and Asia, and the information was obtained from the most senior executives in marketing, manufacturing, and new product development. Of the executives responding, $43 \%$ were from product development, $30 \%$ from marketing, and $27 \%$ from manufacturing. These were also distributed geographically with 59\% from the US, $29 \%$ from Europe, and 13\% from Asia/Pacific. The questionnaire used is available from the authors upon request. In view of confidentiality agreements, the names of the global consulting firm that administered the survey, the detailed responses and the identity of the respondents cannot be made publicly available.

In the following tables that report the results, global centralizers and global de-centralizers were selfidentified by the executives responding to the survey. The global decentralizers were companies where the research and/or development function are organized in a geographically decentralized fashion. The performance and other data were also self-reported on a 5-point scale, and are not based on secondary or publicly available data sources.

\section{KEY RESULTS}

Firms with geographically decentralized NPD generate a greater percentage of their revenues from new products.

To set a benchmark, it would be important to understand the contribution of the new products (in this survey, ones developed in the immediate past three years). The average response obtained was $41 \%$, or forty-one percent of revenues were being derived from products developed in the last three years. This result simply confirms the importance of NPD already reported in a number of executives' surveys. The results were then analyzed separately for companies with geographically decentralized NPD (also referred to as global decentralizers) versus companies with geographically centralized NPD (also referred to as global centralizers). While global decentralizers generated almost $56 \%$ of their revenues from new products, this figure for centralizers was significantly less and stood at less than $30 \%$. Thus, it is clear that there is a significant association between revenues from recently developed products, and the organizational structure supporting NPD.

Global decentralizers however have lower levels of performance on all other performance measures.

Surprisingly however, the greater level of revenues from new product does not translate into superior performance on other dimensions. When asked about the impact of NPD on 17 different measures of performance, senior executives from firms with geographically decentralized NPD reported lower performance on almost all measures of performance used. Table 1 below shows how the senior executives of the global de-centralizers and centralizers perceive their organizational performance. 
Table 1

Performance evaluation since the implementation of product integration strategies (On a scale of 1 to 5, 5 being high)

\begin{tabular}{|l|c|c|}
\hline \multicolumn{1}{|c|}{ EVALUATION MEASURE } & $\begin{array}{c}\text { Globally Decentralized } \\
\text { NPD }\end{array}$ & $\begin{array}{c}\text { Globally Centralized } \\
\text { NPD }\end{array}$ \\
\hline Market-Based Performance Measures: & & 3.57 \\
\hline Return to shareholders & 3.00 & 3.48 \\
\hline Percentage of profits generated from new products & 3.00 & 3.33 \\
\hline Return on technical investment & 3.50 & 3.63 \\
\hline Market share of new products in target markets & & \\
\hline & & 3.31 \\
\hline Product-Based Performance Measures: & 2.74 & 3.32 \\
\hline Speed of new product introduction & 2.95 & 3.32 \\
\hline Product development cycle time & 3.21 & 3.43 \\
\hline Number of new products that meet financial targets & 3.25 & 3.50 \\
\hline Number of new products that meet sales targets & 3.33 & \\
\hline Number of new products that meet cost targets & & \\
\hline & & \\
\hline Customer-Related Performance Measures: & & 3.75 \\
\hline Percentage of customer commitment met & 3.33 & 3.93 \\
\hline Customer satisfaction & $3.42^{*}$ & 3.92 \\
\hline Customer loyalty/retention & 3.69 & \\
\hline & & \\
\hline Labor-Related Performance Measures: & & \\
\hline Labor productivity in product development & \\
\hline Employee turnover during product development cycle & & \\
\hline & & \\
\hline
\end{tabular}

* Significant at $5 \%$

As shown in Table 1, the performance on market-based performance measures is lower for companies with globally decentralized NPD. More importantly, it is significantly lower for the return to shareholders measure. The performance is also lower on all product-based and customer-based measures. It is also significantly lower for customer satisfaction, even though global decentralizers are able to achieve a level of customer retention and meeting customer demand that is not significantly lower than for global centralizers.

As far as employee-based measures are concerned, global de-centralizers again fare worse. The labor productivity in product development is significantly lower than for global centralizers, and they experience a higher level of labor turnover.

Besides the differences in performance between geographic centralizers and de-centralizers, what is striking is the low level of perceived performance recorded across the board. Despite the inclusion in the sample of only large multinational firms, the average (self-reported) performance on any of the performance measures is recorded on a 1 to 5 scale, where 3 means average.

\section{EXPLAINING THE PUZZLE}

The puzzle of greater revenues from new products but lower performance on other measures of performance for firms with globally decentralized NPD is the focus of the reminder of this paper. A number of potential culprits were investigated, and those that were identified as most likely are discussed below.

Control of NPD's performance is less comprehensive at global de-centralizers than at NPD centralizers. 
The next step was to identify what percentage of the respondents used the 14 measures of NPD performance referred to in Table 1. This data is presented in Table 2 below. Global decentralizers were less likely to be using the measures of performance identified as shown in Table 2 below.

Table 2

Percentage of respondents using the following measures of performance to evaluate the product development process

\begin{tabular}{|c|c|c|}
\hline EVALUATION MEASURE & $\begin{array}{c}\text { Globally Decentralized } \\
\text { NPD }\end{array}$ & $\begin{array}{c}\text { Globally Centralized } \\
\text { NPD }\end{array}$ \\
\hline \multicolumn{3}{|l|}{ Market-Based Performance Measures: } \\
\hline Return to shareholders & 53 & 60 \\
\hline Percentage of profits generated from new products & 53 & 65 \\
\hline Return on technical investment & 40 & 60 \\
\hline Market share of new products in target markets & 67 & 75 \\
\hline \multicolumn{3}{|l|}{ Product-Based Performance Measures: } \\
\hline Speed of new product introduction & 67 & 78 \\
\hline Product development cycle time & 67 & 78 \\
\hline Number of new products that meet financial targets & 47 & 70 \\
\hline Number of new products that meet sales targets & $50^{*}$ & 85 \\
\hline Number of new products that meet cost targets & 47 & 70 \\
\hline \multicolumn{3}{|l|}{ Customer-Related Performance Measures: } \\
\hline Percentage of customer commitment met & 57 & 53 \\
\hline Customer satisfaction & 73 & 83 \\
\hline Customer loyalty/retention & 57 & 75 \\
\hline \multicolumn{3}{|l|}{ Labor-Related Performance Measures: } \\
\hline Labor productivity in product development & $30 *$ & 55 \\
\hline Employee turnover during product development cycle & $23 *$ & 48 \\
\hline
\end{tabular}

* Significant at 5\%

On average, only $52 \%$ of global de-centralizers use the measures identified, as opposed to $64 \%$ for global centralizers. The lack of performance monitoring is especially evident in the case of meeting sales target of new product, and in the case of employee-based measures of performance. Only a few of the respondents, whether centralizers or decentralizers, use all the measures identified. Less than 50 percent of both global centralizers and decentralizers are monitoring employee-based measures of new product development. This lacuna is particularly problematic in the light of the significant brain drain observed from large established companies, of which this sample is drawn, towards small entrepreneurial and especially internet-based companies ${ }^{2}$.

\section{NPD STAKEHOLDERS' INVOLVEMENT IN THE NPD PROCESS}

NPD stakeholders are defined in this paper as both the commonly cited internal stakeholders, namely senior executives, the NPD team itself, marketing, and manufacturing functions, and external stakeholders, namely customers, suppliers, and regional offices.

The results are presented below:

Senior executives in firms with globally decentralized NPD are less involved in the NPD process, especially at the idea generation and manufacturing stages. 
Senior executives in firms with globally decentralized NPD were found to have a lower level of involvement in the NPD process, as shown in Table 3 below.

Table 3

Percentage of Senior Executives highly involved in NPD

\begin{tabular}{|c|c|c|}
\hline NPD Stage & $\begin{array}{c}\text { Globally Decentralized } \\
\text { NPD } \\
\end{array}$ & $\begin{array}{c}\text { Globally Centralized } \\
\text { NPD }\end{array}$ \\
\hline 1.Strategy Development & $77 \%$ & $78 \%$ \\
\hline 2.Idea generation/identification & $13 \% *$ & $38 \%$ \\
\hline 3.Product Design & $10 \%$ & $20 \%$ \\
\hline 4.Product Manufacturing & $3 \% *$ & $25 \%$ \\
\hline 5.Project Review and Evaluation & $57 \%$ & $63 \%$ \\
\hline 6.Marketing and Product Rollout & $27 \%$ & $45 \%$ \\
\hline
\end{tabular}

* Significant at $5 \%$

As shown in Table 3 above, for all stages of the NPD process, the executives from companies with globally centralized NPD said that senior managers were involved more than the senior executives from firms with globally decentralized NPD. Moreover, the responses of these executives were statistically significantly different for stages 2 and 4. In stage 2 or the idea generation and identification stage, senior executives from firms with globally decentralized NPD had a very low involvement level (13\%.) Executives from firms with globally centralized NPD however had participation almost 3 times as high at 38\%. At stage 4, the production and manufacturing stage, only $3 \%$ of senior executives had a high level of involvement in companies with globally decentralized NPD while 25\% were involved at this same high level in companies with globally centralized NPD. In numerous companies, NPD manufacturing costs, and manufacturing decisions on scale, quality and other, are of strategic importance, and cannot be neglected.

The involvement of the manufacturing function in NPD is very low in general and significantly lower at the manufacturing stage in firms with globally decentralized NPD.

Just as for senior executives in firms with globally decentralized NPD, manufacturing is less involved in all the stages of the NPD process than in firms with globally centralized NPD. This is obvious from Table 4 below.

Table 4

Percentage of Manufacturing highly involved in NPD

\begin{tabular}{|l|c|c|}
\hline \multicolumn{1}{|c|}{ NPD Stage } & Globally Decentralized NPD & Globally Centralized NPD \\
\hline Strategy Development & $13 \%$ & $25 \%$ \\
\hline Idea generation/identification & $13 \%$ & $23 \%$ \\
\hline Product Design & $33 \%$ & $53 \%$ \\
\hline Product Manufacturing & $67 \% *$ & $88 \%$ \\
\hline Project Review and Evaluation & $30 \%$ & $53 \%$ \\
\hline Marketing and Product Rollout & $13 \%$ & $20 \%$ \\
\hline
\end{tabular}

* Significant at $5 \%$

When asked whether manufacturing had a high level of involvement in the six stages of the NPD process, respondents from firms with globally centralized NPD said yes more often than those from firms with globally decentralized NPD. As shown in Table 4, 88\% of the respondents from firms with globally centralized NPD said the Manufacturing Function had a high level of participation in stage 4, or product manufacturing, of the NPD process. This number is significantly higher than the $67 \%$ obtained for firms with globally de-centralized NPD. 
In the decentralized firms, the manufacturing function is more likely to be handed down a product design and asked to execute with little or no prior consultation. Lower participation of manufacturing at this stage in firms with globally decentralized NPD and low participation by manufacturing at all other stages, especially at the product design stage, is problematic. A likely consequence is costly redesign, when manufacturing cannot manufacture the new product or at least not in a cost-efficient manner. This would result in high manufacturing and redesign costs and longer lead time. This problem would explain the observed higher revenues from new products in conjunctions with higher costs and lower profits and return to shareholders.

Global de-centralization of NPD does not lead to a greater involvement from customers in the NPD process.

One of the key reasons given traditionally for the geographic de-centralization of NPD is the necessity to involve customers more in the NPD process and thus be better able to tailor the products to local customers tastes and needs ${ }^{3}$. Customers however are not more highly involved in firms with geographically de-centralized NPD as shown in Table 5.

Table 5

Percentage of Customers highly involved in NPD

\begin{tabular}{|l|c|c|}
\hline \multicolumn{1}{|c|}{ NPD Stage } & Globally Decentralized NPD & Globally Centralized NPD \\
\hline 1.Strategy Development & $17 \%$ & $28 \%$ \\
\hline 2Idea generation/identification & $53 \%$ & $45 \%$ \\
\hline 3.Product Design & $30 \%$ & $25 \%$ \\
\hline 4.Product Manufacturing & $7 \%$ & $5 \%$ \\
\hline 5.Project Review and Evaluation & $13 \%$ & $25 \%$ \\
\hline 6.Marketing and Product Rollout & $33 \%$ & $38 \%$ \\
\hline
\end{tabular}

* Significant at $5 \%$

Suppliers' involvement in NPD is low, and global de-centralization of NPD does not lead to a greater involvement from suppliers.

Many claims are made about the importance of suppliers, however very few suppliers were found to be involved at a high level in various stages of NPD, as shown in Table 6 below.

Table 6

Percentage of suppliers highly involved in NPD

\begin{tabular}{|l|c|c|}
\hline \multicolumn{1}{|c|}{ NPD Stage } & Globally Decentralized NPD & Globally Centralized NPD \\
\hline 1.Strategy Development & $0 \%$ & $0 \%$ \\
\hline 2.Idea generation/identification & $3 \%$ & $20 \%$ \\
\hline 3.Product Design & $3 \% *$ & $35 \%$ \\
\hline 4.Product Manufacturing & $23 \%$ & $8 \%$ \\
\hline 5.Project Review and Evaluation & $0 \%$ & $10 \%$ \\
\hline 6.Marketing and Product Rollout & $7 \%$ & \\
\hline
\end{tabular}

* Significant at 5\%

Despite the need to be in closer contact with suppliers being given as one of the reason for de-centralization of NPD, firms with geographically decentralized NPD do not involve their suppliers more in the NPD process. Moreover, and as shown in Table 6, suppliers are significantly less involved at stage 4, the product design stage in firms with geographically decentralized NPD. In fact, suppliers' involvement in NPD is close to zero at all stages of 
NPD except at the manufacturing stage where $23 \%$ of the respondents said that their companies involve suppliers highly.

\section{COORDINATION IN NPD}

Given the extent of coordination and team-work involved in NPD, it is instructive to see the extent of ITbased coordination among the respondents.

Geographic de-centralisers are more likely to use IT-based coordination means in the present and in the future.

The respondents were given a list of coordination mechanisms usually used to ensure the coordination of NPD Stakeholders and asked whether their company is currently them. Cross-functional product development teams were mentioned most often despite our findings of a low involvement by manufacturing, NPD, and senior executives in a number of the NPD process stages (see Table 7 below).

Table 7

Methods currently used to ensure coordination of activities among NPD Stakeholders

\begin{tabular}{|l|c|c|}
\hline \multicolumn{1}{|c|}{ COORDINATION METHOD } & $\begin{array}{c}\text { Globally } \\
\text { Decentralized } \\
\text { NPD }\end{array}$ & $\begin{array}{c}\text { Globally } \\
\text { Centralized } \\
\text { NPD }\end{array}$ \\
\hline Traditional Coordination Means: & & $48 \%$ \\
\hline Rewards, incentives, and recognition & $63 \%$ & $85 \%$ \\
\hline Frequent face-to-face meetings & $70 \%$ & $68 \%$ \\
\hline Co-location & $70 \%$ & $90 \%$ \\
\hline Cross-functional product development teams & $87 \%$ & \\
\hline & & $50 \%$ \\
\hline Project/Process-Based Coordination Means: & & $73 \%$ \\
\hline Design For Manufacturing (DFM) & $57 \%$ & $70 \%$ \\
\hline Concurrent product and process design & $67 \%$ & \\
\hline Dedicated program/platform teams & $77 \%$ & \\
\hline & & \\
\hline IT-Based Coordination Means: & & \\
\hline Extranet & $20 \%$ & $30 \%$ \\
\hline Data Warehousing & $33 \%$ & $43 \%$ \\
\hline Intranet & $40 \%$ & $50 \%$ \\
\hline Electronic Data Interchange (EDI) & $80 \% *$ & $43 \%$ \\
\hline Internet & $80 \% *$ & \\
\hline & & \\
\hline
\end{tabular}

* Significant at 5\%

In firms with geographically centralized NPD, the old fashioned face-to-face meetings is still one of the method most often used to insure coordination. While this method of coordination is also commonly used in firms with geographically decentralized R\&D, Electronic Data Interchange and the Internet are preferred by far in those firms. Geographic de-centralizers are also more likely to use IT based coordination means such as EDI and the Internet. Other methods of coordination often used by both centralizers and de-centralizers are concurrent product and process design and co-location. 


\section{DISCUSSION}

In a conceptual paper, Lester (1998) identifies critical success factors for new product development in 5 critical areas. Two of them are senior management commitment, and organizational structure and processes that support the venture.

Using a survey of project managers (broader than just new product development), Besner and Hobbs (2008) identify tools used by project managers and look at whether the nature of the project influences the tool being used. For example, they note that internally focused projects, of which new product development could be one, uses cost/benefit analyses more extensively than externally focused projects.

Looking at the results reported in the earlier section, they appear consistent with the literature in the sense that both a supportive organizational structure and extensive stakeholder involvement are needed for success of new product development. Just having one without the other would not lead to success.

\section{CONCLUSION}

In this paper, we reported on the results of a survey of senior executives on new product development. For firms with globally decentralized new product development, although new products contributed significantly to revenue, executives reported poor operating performance from them. In searching for reasons for such an inability to gain on the advantages of decentralization, what emerged from the survey was that the involvement of senior executives, the manufacturing function, customers and suppliers were all significantly low in such firms. The paper showed that the survey results were consistent with relevant academic research.

Finally, it is worth noting that further work may be needed in this area. For example, it may be necessary to refine the concept of centralization and decentralization. Using a detailed database of managerial job descriptions, reporting relationships, and compensation structures in over 300 large U.S. firms, Rajan and Wulf (2006) find that firm hierarchies are becoming flatter. More executives directly report to the CEO, but, may actually enjoy a greater degree of freedom to make operating and long-term decisions. Furthermore, the compensation appears to increase with greater proximity to the CEO. Given this trend, there is a need to even ask if such "flattening" is consistent with centralization or de-centralization.

\section{ACKNOWLEDGMENTS}

Chacar would like to thank the principals at a global consulting firm for graciously providing the data used in this study and Julian Birkinshaw for providing feedback on an earlier version of this manuscript.

Surysekar gratefully acknowledges the Morrison, Brown, Argiz and Farra, LLP Professorship.

\section{AUTHOR BIOGRAPHIES}

Dr. Aya Chacar is an Assistant Professor in the Management and International Business Department at Florida International University. She is an award winning researcher that focuses on understanding the drivers of value creation by firms and entrepreneurs through innovation, improved firm performance and institutional change. She also examines value appropriation by stakeholders or the distribution of rents, with a focus on strategic human assets. The setting of her research has varied and includes Major League Baseball, the pharmaceutical industry, and the global electronics industry.

Dr. Krishnamurthy Surysekar is an Associate Professor of Accounting and the Morrison, Brown, Argiz \& Farra, LLP Professor at the Florida International University's School of Accounting. His research is in managerial accounting, and his more recent work is cross-disciplinary, involving information, contracting and performance evaluation. His work spans accounting, operations research, organization behavior and information systems. Some of the settings his work has examined include government contracting, centralization and delegation in organizations, defects in manufacturing processes, and knowledge management. 


\section{REFERENCES}

1. Alavi, M., and Leidner, D.E., (2001). Review: Knowledge management and knowledge management systems: Conceptual foundations and research issues. MIS Quarterly, 25(1), 107-136.

2. Baliga, B.R., and Jaeger, A.M., (1984). Multinational corporations: Control systems and delegation issues. Journal of International Business Studies 15(2), 25-40.

3. Besner, C., and Hobbs, B., (2008). Project management practice, generic or contextual: A reality check. Project Management Journal 39(1), 16-33.

4. Chacar, A.S., and Coff, R. (2000). "The Knowledge-Based Employees Paradox". In Bresser, R., Hesuskel, D. and Nixon, R. (Eds.) Winning Strategies in a Deconstructing World. John Wiley \& Sons Ltd: London, UK.

5. Chacar A.S. Coff R. and Surysekar K. (2008) "Implications of Incentives for Knowledge Workers". Review of Business Information Systems. 12(3): 55-60.

6. Chacar, A.S., and Lieberman, M. (2003). "Geographic Organization and Innovation". In Sorenson, Olaf \& Baum, Joel (Eds.) Geography and Strategy -- Advances in Strategic Management, Vol 20.

7. Gilbert, B.A. (2004). The implication of geographic cluster locations for new venture performance. Unpublished Ph.D. dissertation, Indiana University.

8. Hatch, N.W., and Mowery, D.C., (1998). Process Innovation and learning by doing in semiconductor manufacturing, Management Science 44 (11), 1461-1477.

9. Lester, D.H., (1998). Critical success factors for new product development. Research Technology Management 41(1), 36-43.

10. Melumad, N., and Reichelstein, S., (1987). Centralization versus delegation and the value of communication. Journal of Accounting Research 25(1), 1-21.

11. Penner-Hahn, J., (1999), Why R\&D is increasingly international. Financial Times, Nov. 15, 1999, p.10.

12. Rajan, R., and Wolf, J., (2006). The flattening firm: Evidence from panel data on the changing nature of corporate hierarchies. The Review of Economics and Statistics 88(4), 759-773.

13. Severinov, S., (2008). The value of information and optimal organization. Rand Journal of Economics 39(1), 238-265.

14. Tallman, S. and Chacar, A.S. (2009).“Knowledge Accumulation and Dissemination in MNEs: A PracticeBased Framework". Working Paper.

\footnotetext{
${ }^{1}$ In this paper, we use the words "delegation" and "de-centralization" interchangeably.

${ }^{2}$ The importance of employees to innovation in specific and value creation in general is a topic that is gaining importance with the move towards service companies and the realization of the importance of employees' knowledge to the functionnig of the organization. For recent texts addressing this issue, please refer to Chacar and Coff (2000), Chacar, Coff and Surysekar K. (2008), and Chacar and Lieberman (2003).

${ }^{3}$ In fact, historically, closer contact with customers was viewed as the main reason behind the need to decentralize R\&D. Recently however there been a heightened awareness of the importance of other factors such as drawing on local knowledge pools (e.g., Tallman and Chacar, 2009)
} 


\section{NOTES}

